\title{
An Investigation on the Importance of Material Anisotropy in Finite-Element Modeling of the Human Femur
}

\author{
Ryan Krone \\ Lawrence Livermore National Laboratory \\ Peter Schuster \\ Califomia Polytechnic State University
}

Copyright @ 2006 SAE International

\begin{abstract}
Detailed finite element modeling of the human body offers a potential major enhancement to the prediction of injury risk during vehicle impacts. Currently, vehicle crash safety countermeasure development is based on a combination of testing with established anthropomorphic test devices (i.e., ATD or dummy) and a mixture of multibody (dummy) and finite element (vehicle) modeling. If a relatively simple finite element model can be developed to capture additional information beyond the capabilities of the multi-body systems, it would allow improved countermeasure development through more detailed prediction of performance.
\end{abstract}

A simpler finite element model of human bones could be developed if it were shown that less complex finite element material modeling provides sufficient prediction of long bone macro-level strength. This study investigates the importance of including material anisotropy in the finite element model of a human femur. Four composite femur models were developed: linear orthotropic, linear transversely isotropic, linear isotropic, and non-linear isotropic. Each model was used to simulate anterior-posterior (AP) bending and externalinternal rotation. Comparison of the results with physical tests indicates that the global elastic force-deflection response of the whole femur in AP bending is sufficiently described by isotropic material models of the two constituent tissues. The more complex (more detailed anisotropic) material models do not enhance the results of this simulation. However, the global response of the femur in external-internal rotation does indicate that increased material model complexity (or higher degree of detail in material anisotropy) can provide improved prediction capability.

\section{INTRODUCTION}

Finite-element modeling of the human femur, as with most biological structures, has an inherent difficulty in that constructing material models capable of describing the two complex bone tissues, cortical and cancellous, is extremely involved. Therefore the construction of such a finite-element model is much more time consuming and the level of expertise in non-linear material continuum mechanics required to augment accurate material model descriptions is much higher. This caveat necessitates the importance of investigating whether this high degree of material model complexity (mainly in anisotropic description) is necessary.

The human femur has, through numerous investigations, been physically tested (human cadaver whole bones) yielding knowledge on apparent whole-bone properties (e.g. whole-bone elastic bending stiffness $[2,3,4])$. It has also been digitized and modeled in many different finite-element programs both at the tissue level and at the whole-bone macroscopic level $[1,5,6,9,14]$. Much work has also been done to ascertain the femur bone tissue constituents' (cortical and cancellous) linear and non-linear material properties by methods ranging from mechanical and acoustic testing to more theoretical means $[7,8,9,10,11,12,13,15,16,17]$. The more accurate FE models of the femur whole-bone, or separately, the bone tissues, include material models that describe some degree of material anisotropy, or unique directional behavior [5], as well as strain rate dependence.

This study analyzes the behavior of the human right femur as it undergoes deflection-both bending and torsion-imposed by external loads, using a finiteelement model with varying degrees of anisotropy and non-linearity in both the cortical and cancellous tissue material models. The material models are assigned the most current material constants reported in the literature for femur cortical and cancellous bone tissues. The primary focus is to investigate the effects of anisotropy of the material models and, as a corollary, the inclusion of basic nonlinearities to isotropic material descriptions. Strain-rate dependent parameters of the material models are neglected in this study as only static simulations are performed. Anterior-posterior bending is chosen as the 
bending mode because of the availability of physical test data in the literature for validation purposes.

\section{THEORY}

This section presents general descriptions of each of the main material models used in this study (isotropic, transversely isotropic and orthotropic) as well as the independent constants required as inputs to the constitutive equations for each model.

\section{ISOTROPIC MATERIALS}

For an isotropic material, there exist only two independent elastic constants and the constitutive matrix is symmetric regardless of the existence of a strain energy function. The elastic Young's modulus $(E)$, representing the material stiffness (direction independent in isotropic materials) is the slope of the linear stressstrain curve. The Poisson's ratio $(v)$ is the ratio of lateral strain to axial strain. These two parameters are the main material inputs to the isotropic material models used in this study.

\section{TRANSVERSELYISOTROPIC MATERIALS}

A transversely isotropic solid is one that exhibits hexagonally symmetric anisotropic behavior. There are five independent material constants for a transversely isotropic material: two Young's moduli, $E_{1}$ (principal modulus) and $E_{3}$ (or $E_{2}$, modulus in the transverse plane), two shear moduli, $\mathrm{G}_{12}$ (or $\mathrm{G}_{13}$ ) and $\mathrm{G}_{23}$, and one Poisson ratio, $v$.

\section{ORTHOTROPIC MATERIALS}

An orthotropic solid is one that has three mutually orthogonal planes of reflectional symmetry. These materials have mechanical properties that are different in three mutually perpendicular directions at any point in the material body. For an orthotropic body with symmetry, there are nine independent material constants: Young's moduli in three directions $\left(E_{1}, E_{2}\right.$, $\left.E_{3}\right)$, three shear moduli $\left(G_{12}, G_{13}, G_{23}\right)$, and three Poisson's ratios $\left(v_{12}, v_{13}, v_{23}\right)$. These are constrained, in a thermodynamically stable material, by:

$$
\begin{gathered}
E_{1}, E_{2}, E_{3}, G_{12}, G_{23}, G_{31}>0 \\
C_{11}, C_{22}, C_{33}, C_{44}, C_{55}, C_{66}>0 \\
\left(1-U_{23} U_{32}\right),\left(1-U_{13} U_{31}\right),\left(1-U_{12} U_{21}\right)>0 \\
1-\left(U_{12} U_{21}\right)-\left(U_{23} U_{32}\right)-\left(U_{31} U_{13}\right)-2\left(U_{21} U_{32} U_{13}\right)>0
\end{gathered}
$$

Also, by symmetry,

$$
v_{j i}=v_{i j} \frac{E_{j j}}{E_{i i}}
$$

Equations (8b) and (9) together form the following conditions,

$$
\begin{aligned}
& \left|v_{21}\right| \leq\left[\frac{E_{22}}{E_{11}}\right]^{\frac{1}{2}},\left|v_{12}\right| \leq\left[\frac{E_{11}}{E_{22}}\right]^{\frac{1}{2}},\left|v_{32}\right| \leq\left[\frac{E_{33}}{E_{22}}\right]^{\frac{1}{2}} \\
& \left|v_{23}\right| \leq\left[\frac{E_{22}}{E_{33}}\right]^{\frac{1}{2}},\left|v_{31}\right| \leq\left[\frac{E_{33}}{E_{11}}\right]^{\frac{1}{2}},\left|v_{13}\right| \leq\left[\frac{E_{11}}{E_{33}}\right]^{\frac{1}{2}}
\end{aligned}
$$

Equation (8a) is trivially satisfied with the material properties chosen in this study. The conditions of equations (8c), (8d), and (9) are satisfied by the material properties for both cancellous and cortical bone.

\section{MATERIALS AND METHODS}

The original femur model was extracted from a larger, whole lower-limb, finite-element model created for the Radioss FE software package [1]. Before the femur was extracted, the lower-limb model was translated to the FE package LS-DYNA 3D, version 970 (see [18] and [19]). The units of the working FE femur model are $\mathrm{mm}$, msec, $\mathrm{kN}$ and GPa.

Cortical bone tissue in the FE femur is modeled with 3and 4-node shell elements with thickness varying from 2$\mathrm{mm}$ at the bone ends to $5-\mathrm{mm}$ in the shaft. The cancellous bone tissue lies underneath the cortical tissue and is modeled with 6- and 8-node solid elements at the bone ends only (Figure 1). There are shared node connections between the cancellous and cortical bone.

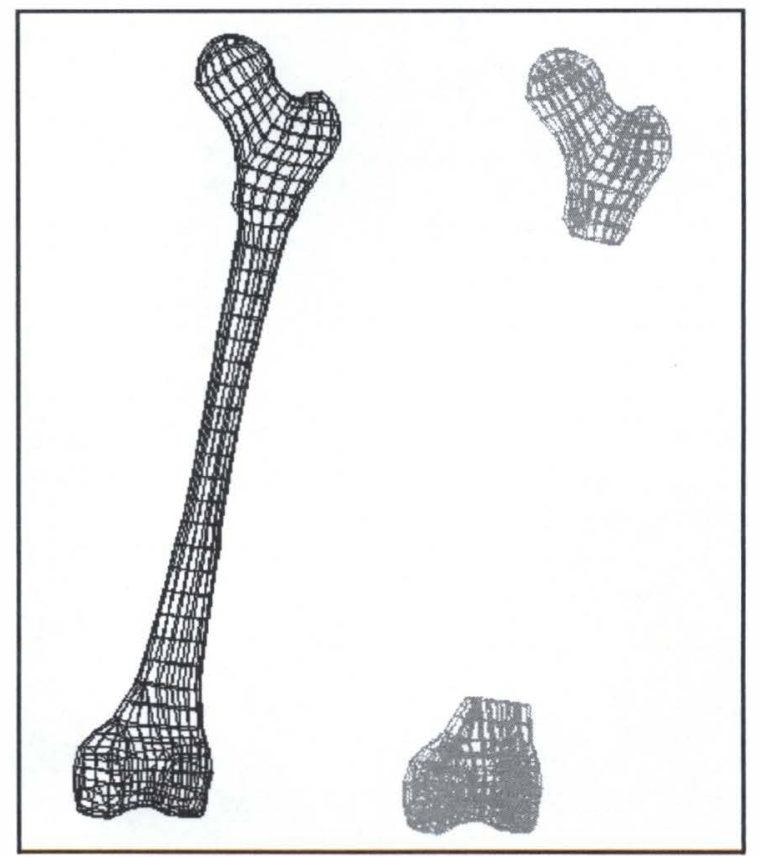

Figure 1: Posterior view showing cortical bone (left) and underlying cancellous bone tissue (right) 


\section{LS DYNA 3D MATERIAL MODELS}

The most important characteristic of the elastic material model descriptions for both the cortical and cancellous bone is that they describe anisotropy-specifically, that there be nine elastic material constant inputs to the material model. To avoid the internal variability in the constitutive equations of different material models, one material model is selected that is compatible for both shell (cortical) and solid (cancellous) elements. This is done to eliminate variation due purely to material model choice.

Two material models were selected for this investigation. See DYNA [19] for complete explanation of these material models. They are summarized below.

\section{Material 02: Orthotropic-Elastic}

Material 02 is termed 'orthotropic elastic', however, in tuning the elastic material properties, this model can also be used to describe a transversely isotropic material and an isotropic material. Material 02 requires nine elastic material constants and the mass density, or apparent density, of the material. This material model is valid for both shell and solid elements and is used in this study for all levels of anisotropy in both the cortical and cancellous bone tissue.

\section{Material 24: Piecewise-Linear-Plasticity}

Material 24 requires the material apparent density, an isotropic Young's modulus and Poisson ratio, the yield stress and the tangent modulus. This model is valid for both shell and solid elements and is used for both the cancellous and cortical bone in investigating simple nonlinearities in the material model description.

\section{BONE MATERIAL CONSTANTS}

Mechanical tensile test data were used when applicable to the conditions of this study. Not all material constants used in this study fall within every range reported in the literature. This variation is expected due the numerous variables including age, pathology, and number of samples. When possible, tabulated tissue response data and average values from multiple studies are used in order to lend the material models 'average' characteristics. This section presents the specific material inputs chosen for each material model. In addition to the mechanical properties listed, the individual bone tissues are prescribed a homogeneous apparent density throughout the femur, for model simplicity, of $1.9 \mathrm{~g} / \mathrm{cm}^{3}$ for cortical tissue and $0.4 \mathrm{~g} / \mathrm{cm}^{3}$ for cancellous tissue.

\section{Cancellous Bone}

Table 1 lists selected orthotropic material properties. These were chosen for the following reasons:

1. All orthogonal moduli fall within a commonly reported range of $0-4.74 \mathrm{GPa}$ [17] and are similar to values reported in [6] and [16].

2. The ratios between the directional Young's moduli show a similar relationship to those found in [12], where $E_{1} / E_{2}$ and $E_{1} / E_{3}$ are equal to about 2 (here equal to 1.4 and 2.0 , respectively) and $E_{3} / E_{2}$ is equal to about 0.6 (here, 0.7 ) for cancellous bone tissue.

3. The average Young's modulus is $1.0 \mathrm{GPa}$, which corresponds to that reported in the literature.

Table 2 and Table 3 show the selected transversely isotropic and isotropic material properties for cancellous bone. Note that for the transversely isotropic material model, the moduli in the 2- and 3- directions were averaged to $822 \mathrm{MPa}$, and the shear moduli in the planes 1-3 and 1-2 were averaged to $399 \mathrm{MPa}$. For the isotropic model, the average Young's modulus of 1.0 GPa is used along with the average Poisson's ratio, 0.3.

Table 4 shows the inputs for the isotropic piecewiselinear-plasticity material model of cancellous bone. The tangent modulus is chosen as $5 \%$ of the elastic modulus, as shown in [11]. The yield stress is the average of values reported in [17] for the greater trochanter, about 3 $\mathrm{MPa}$, and the femoral neck, about $12 \mathrm{MPa}$.

Table 1: Cancellous bone elastic constants for the orthotropic material description

\begin{tabular}{|c|c|c|}
\hline $\begin{array}{c}\text { Young's Moduli } \\
\text { (MPa) }\end{array}$ & $\begin{array}{c}\text { Shear Moduli } \\
\text { (MPa) }\end{array}$ & $\begin{array}{c}\text { Poisson's } \\
\text { Ratios }\end{array}$ \\
\hline$E_{1}=1352$ & $\mathrm{G}_{12}=292$ & $v_{12}=0.30$ \\
\hline $\mathrm{E}_{2}=968$ & $\mathrm{G}_{23}=370$ & $v_{23}=0.30$ \\
\hline $\mathrm{E}_{3}=676$ & $\mathrm{G}_{13}=505$ & $v_{13}=0.30$ \\
\hline
\end{tabular}

Table 2: Cancellous bone elastic constants for the transversely isotropic material description

\begin{tabular}{|c|c|c|}
\hline $\begin{array}{c}\text { Young's Moduli } \\
\text { (MPa) }\end{array}$ & $\begin{array}{c}\text { Shear Moduli } \\
\text { (MPa) }\end{array}$ & $\begin{array}{c}\text { Poisson's } \\
\text { Ratios }\end{array}$ \\
\hline$E_{1}=1352$ & $\mathrm{G}_{12}=399$ & $\mathrm{~V}_{12}=0.30$ \\
\hline $\mathrm{E}_{2}=822$ & $\mathrm{G}_{23}=370$ & $\mathrm{~V}_{23}=0.30$ \\
\hline $\mathrm{E}_{3}=822$ & $\mathrm{G}_{13}=399$ & $\mathrm{~V}_{13}=0.30$ \\
\hline
\end{tabular}

Table 3: Cancellous bone elastic constants for the isotropic material description

\begin{tabular}{|c|c|}
\hline Young's Modulus (GPa) & Poisson's Ratio \\
\hline$E=1.0$ & $v=0.30$ \\
\hline
\end{tabular}

\footnotetext{
Using the range of apparent densities, $0.1 \leq \rho \geq$ 0.70 , and equations $E=1904 p^{1.64}$ (axial loads), $E=1157$ $\rho^{1.78}$ (transverse loads), the moduli range from $44-1060$ $\mathrm{MPa}$ (axial) and $19-613 \mathrm{MPa}$ (transverse).
} 
Table 4: Cancellous bone material constants for the isotropic non-linear model

\begin{tabular}{|c|c|c|c|}
\hline $\begin{array}{c}\text { Elastic } \\
\text { Modulus } \\
(\mathrm{MPa})\end{array}$ & $\begin{array}{c}\text { Tangent } \\
\text { Modulus } \\
(\mathrm{MPa})\end{array}$ & $\begin{array}{c}\text { Poisson's } \\
\text { Ratio }\end{array}$ & $\begin{array}{c}\text { Yield } \\
\text { Stress } \\
(\mathrm{MPa})\end{array}$ \\
\hline $\mathrm{E}=1000$ & $\mathrm{E}_{\tan }=50$ & 0.30 & 7.5 \\
\hline
\end{tabular}

\section{Cortical Bone}

Reilly \& Burnstein [7] are among the few investigators to study the directional moduli of cortical bone. They find:

- $\mathrm{E}_{1}=8.69 \mathrm{GPa}$ (longitudinal),

- $\mathrm{E}_{2}=4.19 \mathrm{GPa}$ (transverse),

- $\mathrm{E}_{3}=3.76 \mathrm{GPa}$ (radial).

Although this $E_{1}$ is significantly lower than most other studies, the data can be used to extract the following ratios, expressed as approximate percentages: $E_{3} / E_{1}=$ $43 \%, E_{3} / E_{2}=90 \%, E_{2} / E_{1}=48 \%$. Table 5 is a comprehensive list of the longitudinal tensile and bending modulus for wet human cortical bone specimens, primarily from the femur [8]. As can be seen, the average of these studies is a longitudinal Young's modulus of $16.0 \mathrm{GPa}$. Using the above percentages, and $E_{1}$ equal to $16.0 \mathrm{GPa}, E_{2}$ and $E_{3}$ are equal to about 6.8 $\mathrm{GPa}$ and $6.3 \mathrm{GPa}$, respectively.

Shear moduli are obtained from Schuster [1] and are similar to the average shear modulus $3.36 \mathrm{GPa}$, as reported in Reilly \& Burnstein [20].

The Poisson's ratios for cortical tissue from Reilly \& Burnstein [20] are equal to 0.62 for "radial specimens" and 0.40 for "longitudinal specimens". However, since these values generated errors in the constitutive equations used for the orthotropic material model (i.e. Poisson ratios greater than 0.5 are not allowed in the infinitesimal theory), the ratios were reduced while keeping their relative magnitudes intact. The Poisson's ratios are scaled down to 0.45 for longitudinal and 0.30 for radial. These are similar to the average Poisson's ratio reported by Katsamanis \& Raftopoulos [21] of 0.36 for femoral cortical bone tissue. The Poisson's ratio for the radially harvested specimen (set to 0.3 ) is also used for the transverse direction Poisson's ratio in this study.

The final nine elastic material constants implemented for the orthotropic cortical bone are reported in Table 6 . The transversely isotropic material model for cortical tissue is simply the orthotropic material model description with $E_{2}=E_{3}=6.30 \mathrm{GPa}$, and $\mathrm{G}_{12}=\mathrm{G}_{13}=$ 3.30 , and is shown in Table 7. The isotropic material model description for cortical tissue is shown in Table 8. Table 9 shows the material constants used for the isotropic piecewise-linear-plasticity material model of cortical bone. The elastic modulus and the Poisson's ratio are the same used for the elastic, isotropic model, the tangent modulus is $5 \%$ of the elastic modulus [11], and the yield stress is an average of values for specimens tested in tension by Reilly \& Burnstein [20].
Table 5: Principal moduli for femoral cortical bone tissue (Choi et al. [8])

\begin{tabular}{|l|c|l|l|}
\hline \multicolumn{2}{|c|}{ Tensile Modulus (GPa) } & \multicolumn{2}{|l|}{ Bending Modulus (GPa) } \\
\hline $\begin{array}{l}\text { Evans \& Lebow } \\
\text { (1951) }\end{array}$ & 14.2 & Sedlin (1965) & 15.8 \\
\hline $\begin{array}{l}\text { Dempster \& Liddicoat } \\
\text { (1952) }\end{array}$ & 14.2 & $\begin{array}{l}\text { Sedlin \& Hirsch } \\
\text { (1966) }\end{array}$ & 15.5 \\
\hline Ko (1953) & 17.3 & Yamada (1970) & 15.7 \\
\hline $\begin{array}{l}\text { Sedlin \& Hirsch } \\
\text { (1966) }\end{array}$ & 6.0 & $\begin{array}{l}\text { Currey \& Butler } \\
\text { (1975) }\end{array}$ & 15.7 \\
\hline Yamada (1970) & 17.2 & $\begin{array}{l}\text { Yang \& Lakes } \\
\text { (1982) }\end{array}$ & 14.4 \\
\hline $\begin{array}{l}\text { Burnstein et al. } \\
\text { (1972) }\end{array}$ & 14.1 & Choi et al. (1990) & 15.2 \\
\hline Reilly et al. (1975) & 17.9 & & 15.4 \\
\hline $\begin{array}{l}\text { Reilly \& Burnstein } \\
\text { (1975) }\end{array}$ & 17.0 & & 15. \\
\hline Avg. (excl. Sedlin) & 16.0 & Avg. & \\
\hline
\end{tabular}

Table 6: Cortical bone elastic constants for the orthotropic material description

\begin{tabular}{|c|c|c|}
\hline $\begin{array}{c}\text { Young's Moduli } \\
\text { (GPa) }\end{array}$ & $\begin{array}{c}\text { Shear Moduli } \\
\text { (GPa) }\end{array}$ & $\begin{array}{c}\text { Poisson's } \\
\text { Ratios }\end{array}$ \\
\hline $\mathrm{E}_{1}=16.0$ & $\mathrm{G}_{12}=3.20$ & $\mathrm{~V}_{12}=0.30$ \\
\hline $\mathrm{E}_{2}=6.88$ & $\mathrm{G}_{23}=3.60$ & $\mathrm{~V}_{23}=0.45$ \\
\hline $\mathrm{E}_{3}=6.30$ & $\mathrm{G}_{13}=3.30$ & $\mathrm{~V}_{13}=0.30$ \\
\hline
\end{tabular}

Table 7: Cortical bone elastic constants for the transversely isotropic material description

\begin{tabular}{|c|c|c|}
\hline $\begin{array}{c}\text { Young's Moduli } \\
(\mathrm{GPa})\end{array}$ & $\begin{array}{c}\text { Shear Moduli } \\
\text { (GPa) }\end{array}$ & $\begin{array}{c}\text { Poisson's } \\
\text { Ratios }\end{array}$ \\
\hline $\mathrm{E}_{1}=16.0$ & $\mathrm{G}_{12}=3.30$ & $\mathrm{~V}_{12}=0.30$ \\
\hline $\mathrm{E}_{2}=6.30$ & $\mathrm{G}_{23}=3.60$ & $\mathrm{~V}_{23}=0.45$ \\
\hline $\mathrm{E}_{3}=6.30$ & $\mathrm{G}_{13}=3.30$ & $\mathrm{v}_{13}=0.30$ \\
\hline
\end{tabular}

Table 8: Cortical bone elastic constants for the isotropic material description

\begin{tabular}{|c|c|}
\hline Young's Moduli (GPa) & Poisson's Ratio \\
\hline $\mathrm{E}=16.0$ & $\mathrm{v}=0.36$ \\
\hline
\end{tabular}

Table 9: Cortical bone material model inputs for the non-linear isotropic model

\begin{tabular}{|c|c|c|c|}
\hline $\begin{array}{c}\text { Elastic } \\
\text { Modulus } \\
(\mathrm{GPa})\end{array}$ & $\begin{array}{c}\text { Tangent } \\
\text { Modulus } \\
(\mathrm{MPa})\end{array}$ & $\begin{array}{c}\text { Poisson } \\
\text { Ratio }\end{array}$ & $\begin{array}{c}\text { Yield } \\
\text { Stress } \\
(\mathrm{MPa})\end{array}$ \\
\hline $\mathrm{E}=16.0$ & $\mathrm{E}_{\tan }=800$ & 0.36 & 108 \\
\hline
\end{tabular}

\section{COORDINATE SYSTEMS}

Due to the complex geometry of the femur bone, it is important to ensure the principal directions are defined correctly for both shell and solid elements. Therefore, a local orthotropic coordinate system is chosen for all shell elements of the cortical bone. This coordinate system definition retains the sensible notion that all the elements 
around the circumference of the shaft of the femur have unique transverse and radial moduli.

The solid elements in the cancellous bone, however, cannot use a locally orthotropic material coordinate system due to the unevenness of the mesh surfaces. The global coordinates system is used to assign a preferred stiffness along the Z-axis, effectively creating a transversely isotropic model. Since the cortical bone experiences the majority of the bending and torsion stresses the lack of a true orthotropic description for the cancellous bone does not compromise this study.

\section{VALIDATION OF THE MATERIAL MODELS}

To avoid errors due to implementation of the directional and material properties, the two femur bone tissue types were evaluated as two tensile test specimens. A solid element sample is used for the cancellous bone tissue and a shell element sample for the cortical bone tissue (solid element sample provided by Dr. Lanny Griffin, Cal Poly, 2004). The loading to the test specimen is implemented through LS DYNA as a load curve that specifies a displacement of $10 \mathrm{~mm}$ over one second. This rate is chosen to avoid dynamic effects such as unwanted plastic straining and distorted elements.

To ensure the coordinate systems of material models were functioning properly, sample material models were run for each tissue and for each option of material principal direction. The output stress/strain curve was then analyzed to ensure the stiffness input for the Zdirection was the stiffness being output by the curve in the Z-direction.

The piecewise-linear-plasticity material models, for both the cancellous and cortical bone, were tested similar to the elastic material models. The shell element and solid element tensile samples were assigned a piecewiselinear-plasticity model to verify material parameters. The yield stress, elastic modulus, and tangent modulus of the material, determined from the output stress and displacement, are compared to the inputs of the material model to ensure consistency.

\section{EVALUATION OF MODELS}

To evaluate how well the individual material models predict the macro-level deformation properties of the human femur, both anterior-posterior (A-P) 3-point bending and pronation-supination (P-S) torsion loading conditions are simulated.

\section{A-P 3-Point Bending}

Boundary conditions are imposed on the femur through rigid bodies defined at the proximal and distal ends (Figure 2). These rigid bodies constrain the motion of the bone and only allow displacement along the long axis (Z-axis) and rotation about the lateral-medial direction (Y-axis) of the bone. The distal rigid body allows rotation about the $\mathrm{Y}$-axis while the proximal rigid body allows both $\mathrm{Y}$-axis rotation and $\mathrm{Z}$-axis translation.

All nodes up to approximately $25 \mathrm{~mm}$ from the distal end and $55 \mathrm{~mm}$ from the proximal end of the femur are included in these rigid bodies. This description simulates a femur under 3-point, A-P bending with ends cemented in plaster. The rotation and translation of each rigid body is prescribed at a center (master) node. Animation of the femur, under anterior-posterior loading, shows deformation consistent with intuition and descriptions of physical testing reported in the literature, validating the chosen rigid body constraints at each end.

The impactor is defined as a 25- $\mathrm{mm}$ diameter hemicylindrical rigid body structure. This structure contacts the anterior mid-diaphysis of the femur (see Figure 3), approximately $220-\mathrm{mm}$ from either end. The impactor is given a fixed velocity $(0.04 \mathrm{~m} / \mathrm{sec})$ for a given amount of time (800-msec), resulting in 32- $\mathrm{mm}$ translation. There is no strain-rate sensitivity in the impact of the femur models and the speed of contact is sufficiently slow to allow strain waves to propagate through the sample before the elements are further deformed.

Failure is not defined for the material models of either tissue in the femur, so the femur must deflect until critical stresses of elements within the femur are reached (as opposed to femur fracture identifiable in the animation). A distance of $32 \mathrm{~mm}$ is sufficient for this.

\section{P-S Torsion}

For pronation-supination torsion loading of the femur, the distal end is constrained in all but translation along the Z-axis. The proximal end of the femur is constrained in all but rotation about the Z-axis, which is specified a fixed rotation rate of $0.28 \% \mathrm{msec}$.

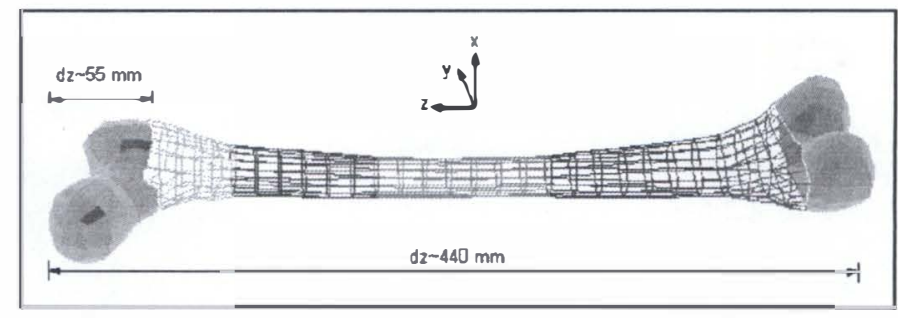

Figure 2: Medial view of the femur model. Rigid bodies are shown as shaded areas.

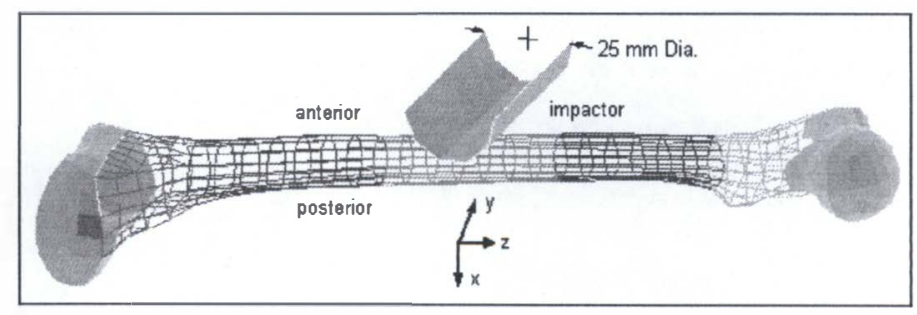

Figure 3: Medial view of the FE femur model showing the impactor and the anterior contact. 


\section{Post Processing}

The following are brief descriptions of the evaluations on each femur done in post processing:

Total Energy: To ensure proper energy input, the total system energy is monitored. This is important in assessing the prediction of the bone fracture point in the non-linear femur models. The plastic energy input to the non-linear simulation is about 30 Joules. Maximum energy before fracture in bending is estimated by Martens et al. [4] to be $36.8 \pm 12.3$ Joules.

Hourglass Energy: This artificial energy did not exceed $10 \%$ of the total strain energy being added to the femur. Most of the hourglass energy was added far from the point of loading, by the deformable elements connected to the rigid body supports.

Rotation Energy: Three-point bending may undergo some unexpected rotation. The rotational energy was monitored and found to be zero for all bending simulations.

Load vs. Deflection: The contact force and impactor translation (for bending simulations) and the applied torque and angle of twist (for torsion) were monitored. This allows direct comparison to physical test results, including curve shape and specific measures (elastic stiffness, proportional limit deflection, proportional limit load, ultimate energy capacity and tangent modulus).

Stress: Contour plots of the $1^{\text {st }}$ and $3^{\text {rd }}$ principal stresses are monitored to ensure the maximum stresses for the cortical tissue do not exceed ultimate stress limits. This is another parameter studied to help identify the readable range of deformation in the femur.

Plastic Strain: Contour plots of the plastic strain are monitored to determine if the linear-elastic models are behaving properly. There should be no plastic strain in the linear-elastic models. For the non-linear model, the plastic strain is tracked to ascertain which regions of the femur deviate from elastic behavior first in bending.

Deformation: An animation of model deformation is monitored to identify abnormalities in the behavior of the bone, such as element distortion or incoherent deformation.

\section{Published Data for FE Model Evaluation}

The goal of this study is to determine the level of anisotropic behavior required to be included in an FE model of a human long bone to achieve accurate macroscopic response predictions. To evaluate the different models developed for this purpose, several published studies reporting 3-point A-P bone bending and P-S torsion test results were collected. Table 10 shows a summary of femur bending and torsion investigations and test conditions used for validation and comparison to the results of this study. The data from these investigations that were used in this study are summarized in Table 11.

Table 10: Femur investigations and test conditions

\begin{tabular}{|c|c|c|}
\hline Type & Comments & Reference \\
\hline $\begin{array}{l}\text { A-P } \\
\text { Bend }\end{array}$ & $\begin{array}{l}\text { 3-pt. static bending, pre and } \\
\text { post yield. Ends in plaster } \\
\text { and hemi cylindrical cups. } \\
\text { Testing of femurs extracted } \\
\text { from } 56 \text { subjects. Mean age } \\
\text { unclear. }\end{array}$ & Mather [2] \\
\hline $\begin{array}{c}\text { A-P } \\
\text { Bend }\end{array}$ & $\begin{array}{l}\text { 3-pt. static bending, pre and } \\
\text { post yield. Ends in plaster. } \\
\text { Impactor head } 20 \mathrm{~mm} \text { dia. } \\
\text { Femurs extracted from } 35 \\
\text { cadavers ranging in age } \\
\text { from } 20-89 \text { years. }\end{array}$ & Yamada [3] \\
\hline $\begin{array}{c}\text { A-P } \\
\text { Bend }\end{array}$ & $\begin{array}{l}\text { 4-pt. quasi-static bending, } \\
\text { elastic range, constant ramp } \\
\text { load } 50 \mathrm{~N}-550 \mathrm{~N} \text {. Roller } \\
\text { contacts. Four rehydrated } \\
\text { and four fresh-frozen } \\
\text { cadaver femurs used. Mean } \\
\text { age unclear. }\end{array}$ & $\begin{array}{l}\text { Cristofolini } \\
\text { et al. [14] }\end{array}$ \\
\hline Torsion & $\begin{array}{l}\text { Four dried-dehydrated and } \\
\text { four fresh-frozen cadaver } \\
\text { femurs were used. Distal } \\
\text { end constrained rotation } \\
\text { about long axis of bone, } \\
\text { proximal end applied torque. } \\
5 \mathrm{Nm} \text { increment loading. }\end{array}$ & $\begin{array}{c}\text { Cristofolini } \\
\text { et al. [14] }\end{array}$ \\
\hline
\end{tabular}

Table 11: Extracted data for comparison and validation to this study

\begin{tabular}{|l|c|c|c|c|}
\hline & \multicolumn{2}{|c|}{ A-P Bending } & \multicolumn{2}{c|}{ Torsion } \\
\hline Source & $\begin{array}{c}\text { Load } \\
\text { Curve }\end{array}$ & $\begin{array}{c}\text { Elastic } \\
\text { Bending } \\
\text { Stiffness } \\
\text { (N/mm) }\end{array}$ & $\begin{array}{c}\text { Load } \\
\text { Curve }\end{array}$ & $\begin{array}{c}\text { Elastic } \\
\text { Torsion } \\
\text { Stiffness } \\
\text { (Nm/) }\end{array}$ \\
\hline Mather [2] & Yes & 364 & No & N/A \\
\hline $\begin{array}{l}\text { Yamada } \\
\text { [3] }\end{array}$ & Yes & 318 & Yes & N/A \\
\hline $\begin{array}{l}\text { Cristofolini } \\
\text { et al. [14] }\end{array}$ & No & $\begin{array}{c}\text { Moment } \\
\text { arm } \\
\text { unclear }\end{array}$ & No & $\begin{array}{c}6.5-10.5 \\
\text { (fresh/frozen) } \\
5.0-9.5 \\
\text { (rehydrated) }\end{array}$ \\
\hline
\end{tabular}

\section{RESULTS}

\section{3-POINT LINEAR A-P BENDING}

Impactor load versus whole bone deflection is the primary output for the anisotropic-elastic femur models and will be the main marker in validating the models to physical tests. Since failure and plasticity are not investigated here, validation of the 3-point A-P bending of the model femur must come from comparisons of 
published numerical values of whole bone elastic stiffness, or equivalently, the initial slope of physical load versus deflection curves.

Yamada [3] shows an A-P bending load versus deflection curve that has an approximate elastic bending stiffness of $318 \mathrm{~N} / \mathrm{mm}$. Mather [2] reports an elastic bending stiffness of $364 \mathrm{~N} / \mathrm{mm}$. For comparison, the orthotropic and transversely isotropic femur models predict a bending stiffness of $278 \mathrm{~N} / \mathrm{mm}$ and the isotropic FE femur predicts $267 \mathrm{~N} / \mathrm{mm}$ (see Table 12).

Table 12: Resulting elastic bending stiffness for each FE femur model

\begin{tabular}{|c|c|}
\hline FE femur model & $\begin{array}{c}\text { Elastic Whole Bone } \\
\text { Bending Stiffness (kN/mm) }\end{array}$ \\
\hline Isotropic & 267 \\
\hline Orthotropic & 278 \\
\hline Transversely Isotropic & 278 \\
\hline
\end{tabular}

The whole bone elastic stiffness for the transversely isotropic model and the orthotropic model are indistinguishable and the isotropic model is $4 \%$ lower when using the material model input moduli listed above.

\section{3-POINT NON-LINEAR A-P BENDING}

Yamada [3] and Mather [2] report 3-point A-P bending femur properties and test curves for comparison with the isotropic-piecewise-plasticity model used in this study. Table 13 summarizes the proportional limit of deflection and the proportional load for each of the published investigations and the model. In addition, Yamada [3] reports the elastic modulus of the femur as 18.34 $\mathrm{kN} / \mathrm{mm}^{2}$ (based on the mid-diaphysis cross sectional properties of the femur, the proportional limit deflection and load) ${ }^{\dagger}$ and the current study shows a similar value of $18.0 \mathrm{kN} / \mathrm{mm}^{2}$.

Table 13: Published whole-bone load versus A-P deflection comparison to FE model

\begin{tabular}{|c|c|c|}
\hline $\begin{array}{c}\text { Load } \\
\text { Curve }\end{array}$ & $\begin{array}{c}\text { Proportional Limit of } \\
\text { Deflection }(\mathrm{mm})\end{array}$ & $\begin{array}{c}\text { Proportional } \\
\text { Load }(\mathrm{kN})\end{array}$ \\
\hline Yamada [3] & $6.0-7.0$ & 2.10 \\
\hline Mather [2] & $6.0-8.0$ & 2.45 \\
\hline FE Model & $8.0-9.0$ & 2.50 \\
\hline
\end{tabular}

\footnotetext{
* The Yamada and Mather stiffnesses are estimated from load curves of single samples in bending. These curves identified the 'average' femur response. ${ }^{\dagger}$ Elastic bending modulus $\left(\mathrm{kN} / \mathrm{mm}^{2}\right), E_{b}=P_{p} L^{3} / 4 b h^{3} \delta_{p}$ where $P_{p}=$ load at proportional limit $(1.75 \mathrm{kN})$, $\mathrm{L}=$ span $(360 \mathrm{~mm}), \mathrm{b}=$ Inner shaft dia. width $(23 \mathrm{~mm}), \mathrm{h}$ $=$ inner shaft dia. Ht. $(20 \mathrm{~mm})$, and $\delta_{p}=$ proportional limit deflection $(6 \mathrm{~mm})$.
}

Figure 4 presents a comparison of the physical results and the isotropic-piecewise-plasticity FE model predictions in 3-point bending.

\section{P.S TORSION}

Yamada [3] reports that "the elastic limit corresponds to about $50 \%$ of the ultimate torsion strength for the femur of every animal." As such, the analysis of the linear FE femur models is restricted to below half of the ultimate torsion strength ${ }^{\ddagger}$ of $45.3 \mathrm{~N} / \mathrm{mm}^{2}$, or $22.7 \mathrm{~N} / \mathrm{mm}^{2}$. The ultimate angle of twist is about $1.5^{\circ}$. Cristofolini et al. [14] reports an elastic stiffness in torsion range for the fresh-frozen femur samples of $6.5-10.5 \mathrm{Nm} /{ }^{\circ}$. The isotropic FE femur model has a higher stiffness of 19.4 $\mathrm{Nm} / \mathrm{deg}$ and the orthotropic and transversely isotropic femur models show a closer (to the literature) stiffness in torsion of $11.64 \mathrm{Nm} / \mathrm{deg}$.

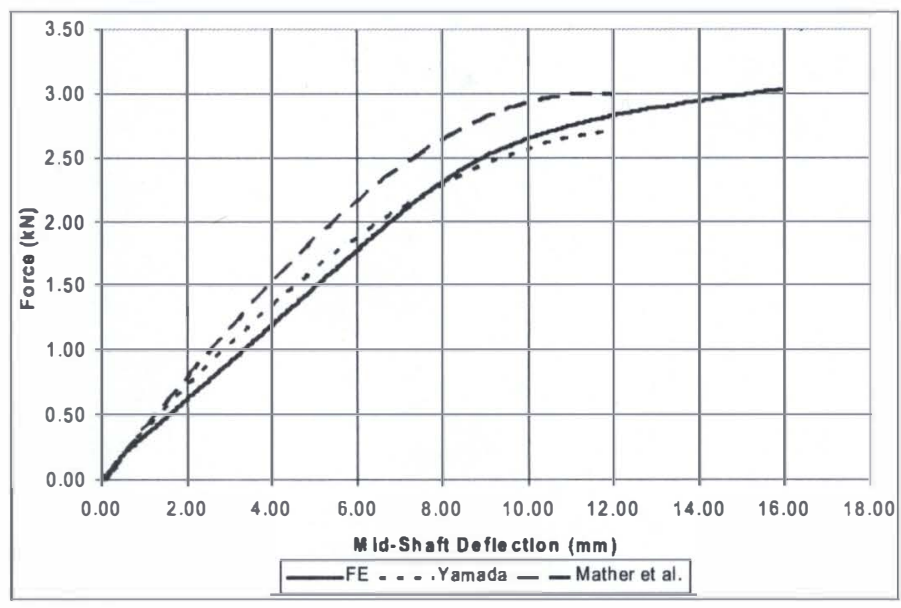

Figure 4: A-P, 3-point bending FE piecewise-plastic femur validation

Table 14 summarizes the elastic whole bone torsion stiffness of each FE femur model. The whole bone elastic torsion stiffness for the transversely isotropic model and the orthotropic model are indistinguishable and the isotropic model is $50 \%$ higher.

Table 14: Resulting elastic torsion stiffness for each FE model

\begin{tabular}{|c|c|}
\hline FE femur model & $\begin{array}{c}\text { Elastic Whole Bone } \\
\text { Torsion Stiffness }\left(\mathrm{Nm} /{ }^{\circ}\right)\end{array}$ \\
\hline Isotropic & 19.4 \\
\hline Orthotropic & 11.64 \\
\hline Transversely Isotropic & 11.64 \\
\hline
\end{tabular}

\footnotetext{
$\ddagger$ Ultimate torsiona strength $(\mathrm{N} / \mathrm{mm} 2)=16 \mathrm{M}_{\mathrm{b}} / \pi \mathrm{D}^{3}$, where $\mathrm{M}_{\mathrm{b}}=$ torsion breaking moment $(\mathrm{N}-\mathrm{mm}), \mathrm{D}=$ diameter $(\mathrm{mm})$
} 


\section{DISCUSSION}

These results support the hypothesis that an isotropic material model-rather than a more complex anisotropic model - of the human femur bone tissues is sufficient to predict whole bone bending response in the linear range. In particular, the transversely isotropic FE model is identical to the orthotropic material model, and both deviate only slightly from the load versus deflection response of the isotropic model. Furthermore, the nonlinear, isotropic model is very similar to the real bone response, as shown in Figure 4, and the inclusion of basic nonlinearities in the material model (as implemented here by a piecewise-linear material model) are important for strains exceeding the linear range.

In contrast, there is a distinct difference in the whole bone response in torsion between the isotropic and anisotropic femur models. The two anisotropic models elicit whole bone responses that are again identical (due to the minute deviation in shear moduli from one model to the other). The isotropic material model has no input for shear modulus, which in turn augments the primary stiffness in the calculations, leading to a much stiffer structure in torsion. The whole bone torsion stiffness of the anisotropic material models is closer to the values shown in the literature and hence indicates anisotropic modeling is recommended for these loading conditions.

The mode of loading on the femur bone dictates the level of anisotropy that should be included in the material model descriptions of the bone tissue constituents. If the whole bone is being loaded in bending, the material models for the cortical and cancellous bone need not describe anisotropy. This result eliminates the necessity of compiling data for and debugging a more complicated FE model for bending evaluations. Since the isotropic FE femur model nearly approximates both the anisotropic FE femur models in bending, it may be used with sufficient accuracy in lieu of the more complicated models. Simplifying the FE model leads to an easier implementation due to the reduced number of material constants required for the simpler material models. This also leads to more time efficient model construction and computation.

In the case of non-linear versus linear isotropic descriptions, the isotropic piecewise-linear-plasticity femur model very closely approximates the physical test load versus deflection curves given in literature (see Figure 4). Since real femur bones behave non-linearly in bending, an FE model that describes non-linear material behavior is a must for significant loads.

Also, in monitoring the stress at specific locations in time of the femur in bending, careful notice must be taken of when the linear range has been exceeded in an element. As the non-linear material model forces a softening behavior of the bone tissue, the areas or groups of elements in the model that reach yield stress levels quickly increase in size as the surrounding elements are recruited to carry more of the stress, and hence, change stiffness themselves. This local plastic strain accounts for the larger number of yielded elements. Figure 5 shows a screen capture of the $1^{\text {st }}$ principal stresses (tensile stresses) on the posterior side of the femur for the isotropic-elastic and isotropic-piecewise-plasticity femur models at the same time step (500 $\mathrm{msec})$.

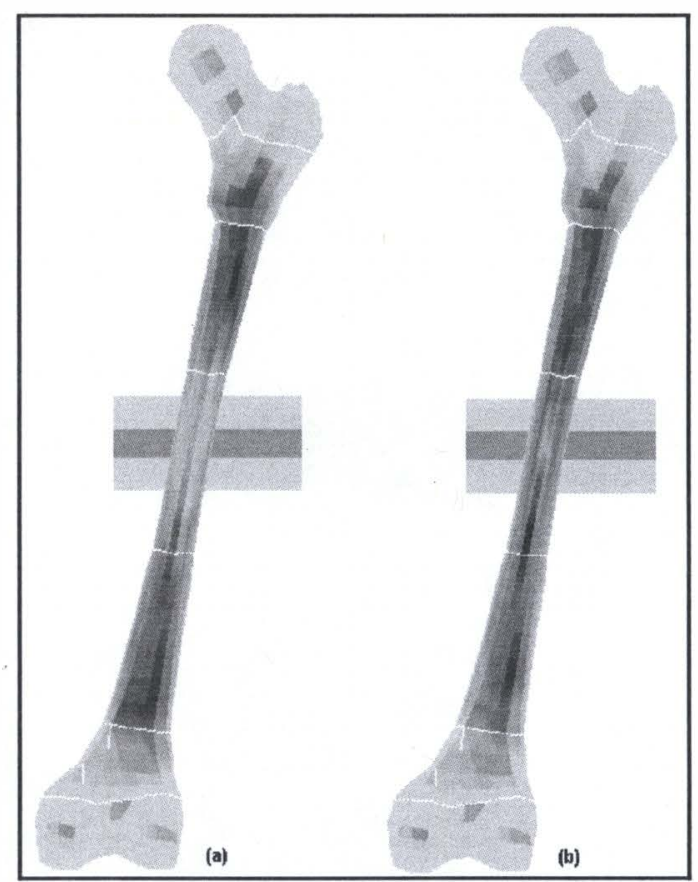

Figure 5: First principal stress in bending for (a) isotropic non-linear and (b) isotropic elastic.

\section{CONCLUSION}

The results obtained in this investigation support the following conclusions:

- Material anisotropy is not necessary for material models of femur bone tissues in the elastic range of whole bone bending.

- Basic non-linear, isotropic material models closely approximate real bone behavior in bending.

- In torsion loading of the whole femur bone, the material model of the bone tissues must include specific shear moduli in the plane of shear.

For implementation of these results into an automotive crash-safety simulation, a relatively detailed finiteelement model showing the injury sequence and material behavior can be evaluated using only isotropic material models when 3-point bending is the prevailing loading mode. This greatly reduces both the time and expertise involved in augmenting more complicated material model descriptions. However, if non-negligible torsion is present, care must be taken to include appropriate directional shear moduli into the FE material model description. 


\section{ACKNOWLEGEMENTS}

This work was funded by a California State University Faculty Support Grant at California Polytechnic State University, San Luis Obispo.

\section{REFERENCES}

1. Schuster PJ, Jayaraman G, Chou CC, Prasad P, "Development and validation of a pedestrian lower limb non-linear 3-D finite element model." Stapp Car Crash Journal 44: Paper \# 2000-01-SC21 (2000).

2. Mather BS, "Correlations Between Strength and Other Properties of Long Bones." Journal of Trauma 7(5): 633-638, 1967.

3. Yamada H, Strength of Biological Materials. Evans FG, Editor. Baltimore: Williams and Wilkins, 1970.

4. Martens M, Van Audekercke R, de Meester P, Mulier JC, "Mechanical Behavior of Femoral Bones in Bending Loading." Journal of Biomechanics 19(6): 443-454, 1986.

5. Pellettiere JA, A Dynamic Material Model for Bone. Dissertation, University of Virginia January, 1999.

6. Wirtz DC, Schiffers N, Pandorf T, Radermacher K, Weichert D, Forst R, " Critical Evaluation of Known Bone Material Properties to Realize Anisotropic FESimulation of the Proximal Femur." Journal of Biomechanics 33: 1325-1330, 2000.

7. Reilly DT, Burnstein AH, "The Mechanical Properties of Cortical Bone." Journal of Bone and Joint Surgery 56:A(5), 1974.

8. Choi K, Kuhn JL, Ciarelli MJ, Goldstein SA, "The Elastic Moduli of Human Subchondral Trabecular and Cortical Bone Tissue and the Size-Dependency of Cortical Bone Modulus." Journal of Biomechanics 23(11): 1103-1113, 1990.

9. Ciarelli MJ, Goldstein SA, Kuhn JL, Cody DD, Brown $M B$, "Evaluation of Orthogonal Mechanical Properties and Density of Human Trabecular Bone from the Major Metaphysis Regions with Materials Testing and Computed Tomography." Journal of Orthopaedic Research 9(5): 674-682, 1991.

10. Keaveny TM, Guo XE, Wachtel EF, McMahon TA, Hayes WC, "Trabecular Bone Exhibits Fully Linear Elastic Behavior and Yields at Low Strains." Journal of Biomechanics 27(9): 1127-1136, 1994.

11. Bayraktar HH, Morgan EF, Niebur GL, Morris GE, Wong EK, Keaveny TM, "Comparison of the Elastic and Yield Properties of Human Femoral Trabecular and Cortical Bone Tissue." Journal of Biomechanics 37: 27-35, 2004.

12. Augat $\mathrm{P}$, Link T, Lang TF, Lin JC, Majumdar S, Genant HK, "Anisotropy of the Elastic Modulus of Trabecular Bone Specimens from Different Anatomical Locations." Journal of Biomechanics 20: 124-131, 1998.

13. Zysset PK, "A Review of Morphology-Elasticity Relationships n Human Trabecular Bone: Theories and Experiments." Journal of Biomechanics 36: 1469-1485, 2003.
14. Cristofolini L, Viceconti M, Cappello A, Toni A, "Mechanical Validation of Whole Bone Composite Femur Models." Journal of Biomechanics 29(4): 525535, 1996.

15. Kabel J, Van Rietbergen B, Dalstra M, Odgaard A, Huiskes R, "The Role of an Effective Isotropic Tissue Modulus in the Elastic Properties of Cancellous Bone." Journal of Biomechanics 32: 673-680, 1999.

16. Morgan EF, Bayraktar HH, Keaveny TM, "Trabecular Bone Modulus-Density Relationships Depend on Anatomic Site." Journal of Biomechanics 36: 897904, 2003.

17. Morgan EF and Keaveny TM, "Dependence of Yield Strain of Human Trabecular Bone on Anatomic Site." Journal of Biomechanics 34: 568-577, 2001.

18. LS DYNA 3D version 970, April 2003. Keyword User's Manual. Livermore Software Technology Corporation. 1992-2003.

19. LS DYNA 3D, May 1998. Theoretical Manual. Compiled by Hallquist JO, Livermore Software Technology Corporation. 1991-1998.

20. Reilly DT, Burnstein AH, "The Elastic and Ultimate Properties of Compact Bone Tissue." Journal of Biomechanics 8: $393 \mathrm{ff}, 1975$.

21. Katsamanis F and Raftopoulos DD, "Determination of Mechanical Properties for Human Femoral Cortical Bone by the Hopkinson Bar Stress Technique." Journal of Biomechanics 23(11): 11731184, 1990. 